SECTION 19. Management. Marketing. Public administration.

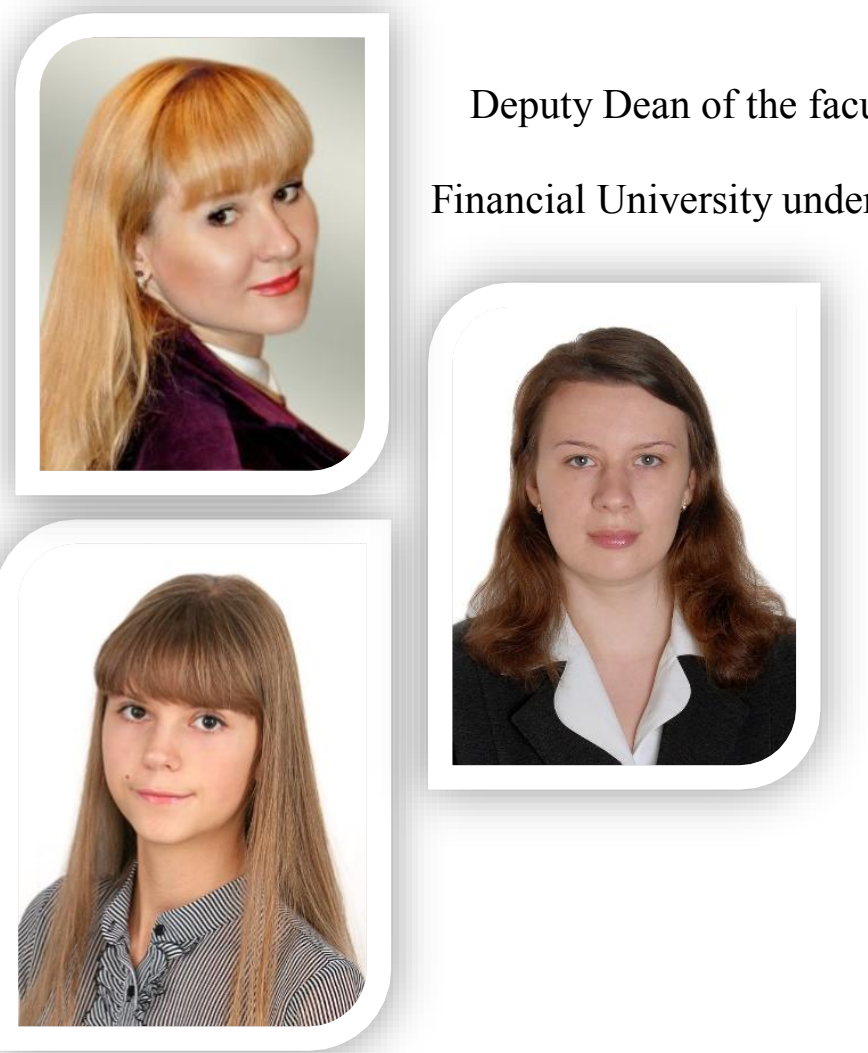

Tatiana Vitalievna Butova Deputy Dean of the faculty of Public and municipal administration, Candidate of Economic Science, Docent Financial University under the Government of the Russian Federation tvbutova@mail.ru

Marina Konstantinovna Krivtsova third year student, bachelor, Financial University under the Government of the Russian Federation marinstar@,bk.ru

Maria Aleksandrovna Podzorova third year student, bachelor Financial University under the Government of the Russian Federation marusia15@inbox.ru

\title{
THE SUBJECTS AND OBJECTS OF PUBLIC ADMINISTRATION OF FORESTRY OF THE RUSSIAN FEDERATION
}

Abstract: In this work the subjects and objects of public administration of forestry of the Russian Federation are characterized. The analysis of the standards and legal base which regulate Russian forestry management is carried out. Forest areas and forest parks as the main objects of public administration in the forestry control system are touched upon as well. forestry

Key words: Federal forestry agency, woods, public administration, Federal Nature Management Supervision Service, Forest code, forest parks, forest areas.

\section{СУБЪЕКТЫ И ОБЪЕКТЫ ГОСУДАРСТВЕННОГО УПРАВЛЕНИЯ ЛЕСНЫМ ХОЗЯЙСТВОМ РОССИЙСКОЙ ФЕДЕРАЦИИ}

Аннотация: В данной работе дается характеристика субъектам и объектам государственного управления лесным хозяйством Российской Федераџии. Проводится анализ нормативно-правовой базы, регулирующей управление лесным хозяйством России. Отдельно отмечаются лесничества и лесопарки как основные объекты государственного управления в системе управления лесным хозяйством. лесное хозяйство

Ключевые слова: Рослесхоз, леса, государственное управление, Росприроднадзор, Лесной кодекс, лесопарки, лесничества.

В настоящее время основными органами исполнительной власти, осуществляющими государственное управление лесным хозяйством в Российской Федерации, являются:

- Федеральное агентство лесного хозяйства (Рослесхоз); 
- Министерство природных ресурсов и экологии Российской Федерации (Минприроды России);

- Федеральная служба по надзору в сфере природопользования (Росприроднадзор). [1, с. 17]

Основным федеральным органом исполнительной власти в сфере лесных отношений на федеральном уровне является Федеральное агентство лесного хозяйства (Рослесхоз), которое в соответствии с Указом Президента Российской Федерации от 21 мая 2012 г. №636«О структуре федеральных органов исполнительной власти» находится в ведении Министерства природных ресурсов и экологии Российской Федерации. [5, с. 26]

В соответствии с постановлением Правительства Российской Федерации от 23 сентября 2010 г. № 736 «О Федеральном агентстве лесного хозяйства» Федеральное агентство лесного хозяйства (Рослесхоз) осуществляет следующие функции:

- по контролю и надзору в области лесных отношений (за исключением лесов, расположенных на особо охраняемых природных территориях);

- по оказанию государственных услуг и управлению государственным имуществом в области лесных отношений;

- по отнесению лесов к защитным лесам (за исключением случая, предусмотренного пунктом 1.1 статьи 82 Лесного кодекса Российской Федерации) и выделению особо защитных участков, установлению и изменению их границ;

- по отнесению лесов к эксплуатационным, резервным лесам, установлению и изменению их границ;

- по осуществлению государственной инвентаризации лесов;

- по осуществлению государственного пожарного надзора и государственного лесного контроля и надзора на землях лесного фонда в отношении лесничеств и лесопарков, указанных в части 2 статьи 83 Лесного кодекса Российской Федерации, в лесах, расположенных на землях обороны и безопасности, и в случаях, когда полномочия, переданные Российской Федерацией органам государственной власти субъектов Российской Федерации в соответствии с частью 1 статьи 83 Лесного кодекса Российской Федерации, изъяты в установленном порядке у органов государственной власти субъектов Российской Федерации;

- по организации и обеспечению лесопатологического мониторинга в лесах, расположенных на землях лесного фонда и иные полномочия.

Штатная численность Рослесхоза, установленная постановлением Правительства Российской Федерации от 18 февраля 2013 г. № 137, является информацией для служебного пользования и недоступна для анализа в рамках настоящей дипломной работы. [2, с. $32 ; 10$, с. 117]

В то же время ранее (до 1 апреля 2013 года) штатная численность Рослесхоза была установлена постановлением Правительства от 28 января 2011 г. № 39, можно предположить, что она претерпела незначительные изменения. Таким образом, в соответствии с указанным постановлением Правительства Российской Федерации, штатная численность Рослесхоза составляла:

- для центрального аппарата -254 штатные единицы;

- для территориальных органов - 782 штатные единицы.

Территориальные органы Рослесхоза образованы на основе федеральных округов Российской Федерации, в настоящее время функционирует 7 территориальных органов Рослесхоза. Таким образом, средняя штатная численность указанных территориальных органов составляет 111 штатных единиц. [9, с. 82]

В соответствии с пунктом 5.2.45 Положения о Минприроды России, утвержденного постановлением Правительства Российской Федерации от 29 мая 2008 г. № 404, Министерство принимает нормативные акты, устанавливающие особенности 
использования, охраны, защиты и воспроизводства лесов, расположенных на особо охраняемых природных территориях, а также осуществляет функции по выработке государственной политики и нормативно-правовому регулированию в сфере изучения, использования, воспроизводства и охраны природных ресурсов, включая недра, водные объекты, леса. [3, с. 301; 7, с. 63]

Федеральная служба по надзору в сфере природопользования (Росприроднадзор) в соответствии с Положением, утвержденным постановлением Правительства Российской Федерации от 30 июля 2004 г. № 400, является федеральным органом исполнительной власти, осуществляющим функции по контролю и надзору в сфере природопользования, а также в пределах своей компетенции в области охраны окружающей среды, в том числе в части, касающейся ограничения негативного техногенного воздействия, в области обращения с отходами (за исключением радиоактивных отходов) и государственной экологической экспертизы.

В частности, на Росприроднадзор возложены полномочия по осуществлению федерального государственного лесного надзора в лесах, расположенных на землях особо охраняемых природных территориях федерального значения.

Основным объектом государственного управления в системе управления лесным хозяйством являются лесничества и лесопарки. [6, с. 32]

В соответствии со статьей 23 Лесного кодекса Российской Федерации все земли лесного фонда Российской Федерации должны быть разделены уполномоченным федеральным органом исполнительной власти (Рослесхозом) на лесничества и лесопарки, которые представляют собой территориальные единицы управления лесным хозяйством страны.

В отношении лесничеств, лесопарков осуществляются установление расчетной лесосеки, проведение лесоустройства, разработка и утверждение лесохозяйственных регламентов, ведение государственного лесного реестра. [9, с. 244]

Кроме того, лесничества и лесопарки являются объектом управления со стороны лесохозяйственного регламента, являющегося основным документом для организации осуществления, использования, охраны, защиты, воспроизводства лесов в Российской Федерации.

Следует отметить, что Лесной кодекс Российской Федерации не раскрывает содержание данных понятий.

В соответствии с определениями, предлагаемыми экспертами, лесничество может рассматриваться как основная территориальная единица управления лесным хозяйством в Российской Федерации.

При этом под лесопарком можно понимать частично искусственно образованный или благоустроенный лес, расположенный в пределах территории города или иного населенного пункта.

Лесопарк предназначен, в первую очередь, для организации и обеспечения отдыха населения. Лесопарки могут занимать значительную площадь - от нескольких сотен до 2 - 3 тысяч га и более. [4, с. 67].

\section{References:}

1. Арбузова Т.В. Совершенствование организационной структуры управления лесным хозяйством // Известия Российского государственного педагогического университета им. А.И. Герцена. 2008. № 73-1.

2. Артамонова В.О. Государственное управление в сфере охраны и защиты лесов // Актуальные проблемы российского права, 2013, № 8.

3. Атаманчук Г. В. Управление: сущность, ценность, эффективность. - М.: Академический проект, 2006. 
4. Гиряев М.Д., Кеникстул В.И., Глебов В.П. Совершенствовать систему управления лесным хозяйством // АПК: Экономика, управление. 2009. № 5.

5. Клейнхоф И.А. Реформирование системы управления лесами и лесным хозяйством через призму кризисных ситуаций // Национальные интересы: приоритеты и безопасность. 2011. № 5.

6. Оленина Т.Ю. Правовые аспекты лесного планирования как административноправовой формы государственного регулирования лесных правоотношений // Административное право и процесс, 2013, № 7.

7. Паршута В.В. Государственное управление лесами // Административное право и процесс, 2011, № 3

8. Рагулина Ю.В. Инновационный потенциал организации как фактор конкурентоспособности. // Материалы научно-практической конференции «Проблемы сохранения экономического и экологического баланса в России во взаимодействии с тенденциями поступательного развития экономики». М.: МГОУ, 2011.

9. Седов А.А. Функции управления лесным хозяйством // Актуальные проблемы российского права. 2007. № 1.

10. Якунин В.И. Теоретические аспекты проблемы эффективности государственного управления // Журнал «Власть», №8, 2006. 